\title{
The teacher's body elements that influence the teaching-learning process of university nursing students
}

\author{
Paulo Sérgio da Silva' \\ Nébia Maria Almeida de Figueiredo²
}

\section{The teacher's body elements that influence the teaching-learning process of university nursing students}

Objective. To identify the body elements of the teacher that influence the teaching-learning process and to analyze their effects on university nursing students. Methods. Qualitative research with descriptive approach implemented through a dramatic play dynamics. In the second half of 2015, sixteen students from a private university center located in Rio de Janeiro (Brazil) participated in the study. The data processing was carried out by using Bardin's theoretical and analytical framework. Results. Four decoding units were created. They verse about the teacher's positioning, body movements, eyes, facial expressions as well as the clothes used to teach nursing. Conclusion. The teacher's elements are capable of generating effects that influence the process of learning nursing. This leads us to believe that the body should continue to be an object of study and discussion in the higher education of nurses.
Descriptors: education, nursing; faculty, nursing; students, nursing.

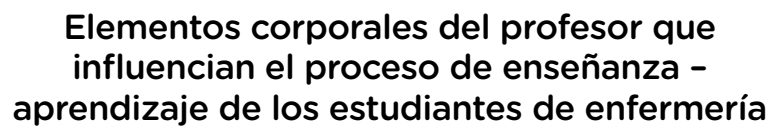

Objetivo. Identificar los elementos corporales del docente que influencian el proceso de enseñanza-aprendizaje y analizar sus efectos en los estudiantes de enfermería. Métodos. Investigación cualitativa con abordaje descriptiva mediante la dinámica del juego dramático. 16 estudiantes de una universidad privada ubicada en el estado de Río de Janeiro (Brasil) participaron en el estudio. El tratamiento de los datos se realizó con el referencial teórico-analítico de Bardin. Resultados. Se encontraron cuatro unidades de decodificación que trataron sobre: posición y movimientos corporales, los movimentos de los ojos, las expresiones faciales y la ropa utilizada por el docente para enseñar enfermería. Conclusión. Los elementos corporales identificados

1 Nurse, Ph.D. Professor, Serra dos Órgãos University Center (UNIFESO). Teresópolis (RJ), Brazil. email: pssilva2008@ gmail.com

2 Nurse, Ph.D. Professor Emeritus, Federal University of the State of Rio de Janeiro. Rio de Janeiro (RJ), Brazil. email: nebia@unirio.br

Article linked to research: Marcas do corpo do professor na formação de enfermeiros: um estudo sobre egressos nos cenários de cuidar.

Conflicts of interest: None.

Received: February 22nd 2017.

Accepted: July 26th 2017.

How to cite this article: Silva PS, Figueiredo NMA. The teacher's body elements that influence the teaching-learning process of university nursing students. Invest. Educ. Enferm. 2017; 35(3). 268-275

DOI: 10.17533/udea.iee.v35n3a03 
en el docente producen efectos que influencian el proceso de aprendizaje de enfermería. En este sentido, es fundamental el ejercicio del diálogo que incidan en la expresividad del cuerpo para enseñar y reconocerlo como objeto de estudio y discusión en la formación superior de la enfermería.

Descriptores: educación en enfermería; docentes de enfermería; estudiantes de enfermería.

\section{Elementos corporais do professor que influenciam o processo de ensino- aprendizagem estudantes universitários de enfermagem}

Objetivos. Identificar os elementos corporais do professor que influenciam o processo de ensinoaprendizagem e analisar seus efeitos nos corpos dos estudantes universitários de enfermagem. Métodos.

\section{Introduction}

Nursing teachers experience the challenges of modernity every day when teaching students or reflecting with them on the various issues related to the caregiving profession. In this way of thinking, teachers use body language in diverse teaching-learning scenarios to present to students the aspects inherent to nursing care. Specifically, gestures, smiles, and body movements are some examples of this expressiveness present in the teaching practice. Yes, it is necessary to decode all this expression located in the intimacy of the meeting established between the teachers and the university nursing students. In this light, it is necessary to open up to investigate the elements present in the body that teaches, which is revealed in the scope of a complex activity and produces subjective zones to think on the training of nurses in a perspective of producing effects and generating responses in the body who learns. ${ }^{(1)}$

The dimension of the body is thus designed to elicit reflections regarding the process of training nurses and to find a whole theoretical substrate in the discourses of subjectivity. Specifically in nursing, the body can be understood as
Pesquisa qualitativa com abordagem descritiva induzida pelo jogo dramático. Participaram do estudo 16 estudantes de um centro universitário particular localizado no Rio de Janeiro. O tratamento dos dados foi realizado a partir do referencial teórico-analítico de Bardin. Resultados. Foram criadas quatro unidades de decodificação que versam sobre: posicionamento e movimento corporal do professor, movimentos dos olhos, as expressões faciais e as roupas utilizadas para ensinar enfermagem. Conclusão. Os elementos corporais identificados no professor foram capazes de gerar efeitos que influenciam o processo de aprender enfermagem. Nesse sentido, é fundamental exercitar diálogos que incidam na expressividade do corpo para ensinar, reconhecidos como objeto de estudo e discussão no âmbito da formação superior de enfermeiros.

Descritores: educação em enfermagem; docentes de enfermagem; estudantes de enfermagem.

the minimum space, owner of its own ideas, opinions, values, ambitions and worldview. It is the place of expression and creation, of meaning and representations, of production of images, power and product of subjectivity, instituted and instituting, that makes political movements of change. (2) In this context, to stimulate the protagonists involved in the teaching to think about their professional identity, it is necessary to overcome the challenge of breaking with rigid curricular structures, evaluations that exclusively focus on contents that deal with diseases and automatism rooted in the pedagogical strategies adopted by teachers to teach.

It is necessary to consider the processes that naturalize the change of higher education in a commercial product, intensifying the precariousness of activities of the university teacher. Yes, the current context challenges those who teach. Languages, technology, and pedagogical practices, in general, through which subjectivities are produced in the modern world, are object of discussion. ${ }^{(3)}$ The challenge consolidated is the attempt to avoid trivializing the actions of caring and the human relations produced in university 
banks. To think the solidarity, justice, economic issues; to live and dream about teaching with direct impacts on the world of work; never to neglect simple and possible practices at the expense of just believing in technologies. Teachers concerned by this problematic have located here their bodydesire in a globalized society. Certainly, there is no separation between the phenomena that surround the world and the bodies that teach nursing care. It is in this aspect that the world penetrates into the soul of the teacher, and is consequently analyzed by students who learn nursing.

These connections between the body and the world, and between the world with teaching, authorize the presentation of the following guiding question of this investigative essay: what are the physical elements of the nursing teacher that influence the teaching-learning process? In order to respond to this question, the following objectives were defined: to identify the teacher's body elements that influence the teaching-learning process and analyze its effects on the bodies of university nursing students.

\section{Methods}

\section{On the methodological orientation of the study and the characteristics of the researcher}

The method used in this research was qualitative with descriptive approach induced by a dramatic game dynamics. ${ }^{(4,5)}$ In this methodological orientation, the male researcher was theoretically instrumented by disciplines, such as: knowledge theory, fundamental bases for qualitative studies and conversations with professors and nurses from the University of Évora and Bologna. At the time of the investigation, the interviewer had the degree of Master of Nursing enrolled in the second year of the Graduate Course in Nursing and Biosciences - Doctorate.

\section{On the study site and ethical aspects of research}

Regarding the study site: a nursing undergraduate course was selected from a private university center located in the mountain region of the state of Rio de Janeiro, Brazil, whose curriculum is guided by active teaching-learning methodologies. In the second half of 2015 , the interviews were held in four different meetings with the participation of four students in a previously selected classroom. The duration of the meetings with each focal group were: first group, 1 hour and 18 minutes; second group, 58 minutes and 37 seconds; third group, 1 hour and 43 minutes and, finally, fourth group, 1 hour, 37 minutes and 18 seconds. Saturation in data production was observed in the third group of respondents.

In order to guide the interviews, five moments of game were created ( $A, B, C, D$ and $E)$, with instructions for working with imagery resources. ${ }^{(6)}$ At the moment $A$, there was a meeting with four participants per game. They were invited to occupy the classroom area in a free and comfortable way. In step B, the imaginary password was distributed, which consisted of an inductive question with the purpose of retrieving the mental images experienced by the nursing students about the bodies of the teachers during graduation. This retrospective gymnastics of the imaginary was induced by the following unstructured questioning: based on academic experiences, highlight the elements of the nursing teachers' bodies that influenced your training process.

After the distribution of the imaginary password, the moment $\mathrm{C}$ was activated, characterized by the collective presentation and sharing of the mental images experienced by the students during the training process. When discussions were saturated, the participants were invited to enter the moment $D$, marked by the distribution of a fixed image, which depicts the meeting with the teacher's body in the upright position, touching with one hand the shoulder of the student that is sitting in the chair looking carefully to the notebook. After this, at the moment, the participants were invited to dialogue with the mental images experienced and with the fixed image, articulating new meanings to the teaching-learning process experienced with the teachers. 
Repeated interviews were not taken into account and the interviewer was careful to organize all the speeches in the dramatic game, which were recorded in an MP3 player, transcribed and presented to the participants. After the reading of its contents, the use of the recordings for scientific purposes was authorized by them. It should be noted that the impressions during the production of the data were recorded in a field diary to aid in the discussion of the findings. Regarding the ethical aspects, the study was sent to the coordinator of the nursing course for appreciation. Once approved, the project was submitted to the Research Ethics Committee (REC), where was approved under Opinion registered with memorandum number 804.017. It should be noted that all participants in this research signed the Free and Informed Consent Term following the guidelines of Resolution 466/2012 of the National Health Council.

\section{On the selection and relation between participants and the researcher}

The study sample was intentionally selected taking into account the nursing graduation time; the last class of the course was prioritized because of the greater contact with the institutional teaching staff. Participants were invited to participate in the study on the first day of class. At this meeting, the telephones and electronic addresses of the interested parties were collected for the scheduling of dates, times and rooms where the interviews would take place. Fifteen participants declined to participate in the study, claiming that they were unavailable for the meeting, ashamed to speak in group and shy about the audio recorder. There was no withdrawal among the 16 participants included during data collection. Regarding the relationship established between the interviewer and the participants included in the research: the only meeting occurred prior to the production of the data during the official invitation to participate in the study. Thus, the nursing students had no previous pedagogical contact with the researcher during the nursing training.

\section{On data analysis and nursing vision for research}

The data from the dramatic game were analyzed according to their content, under the theoretical framework of Bardin. ${ }^{(7)}$ This analysis was done manually by two researchers separately who in a third moment met to match the findings. Therefore, no software was used for data processing. All the contents arranged in the manuscript derive exclusively from the data production and the authors provide a description about the decoding tree based on the teacher's body elements that produced effects in the nursing students when they learning the work of providing care. After the conclusion of the final thesis report, the participants had access to reading the entire study and authorized the publication in Nursing periodicals. The statements of the participants in the manuscript were presented, and in order to guarantee their confidentiality, the identification word "Student" was assigned followed by the ordinal number from the investigative pathway experienced in the data production.

The contents were arranged in four decoding units in order of expressiveness of the investigative findings, from highest to lowest. The data were compared with studies published in national and international journals that deal with the object of study, that is, the teacher's body. Here, we recognized the investigations local coverage as a methodological limitation. Certainly, this raises the desire of the study to be expanded and replicated in other contexts of higher education in nursing. This is because this investigative experience allowed us to think about the teaching-learning process in nursing as a permanent movement of reflection on the process of subjectivities, that is, to train and to produce. In this case, the process of producing nurses. This is not possible without an adventure in the field of subjectivity. In this way, the teacher's body has, conceptually, a broader meaning, which is a body that individualizes itself. A collective body of teachers from a higher education institution, but also a theoretical-conceptual corpus of this Nursing that enters into a training process to meet the demands of health in its different magnitudes and contexts.

\section{Results}

The content analysis of the nursing students' testimonies identified the positioning, body 
movements, the way of looking, the appearance and the facial expressions of the teacher as body elements that should be thought, problematized and discussed in the scope of the superior education of nurses. Some statements that represent the four decodificated units identified are presented below:

\section{First unit: the teacher's positioning and body movement}

[...] the teacher, when sitting, is closer to you ... it is that person who is not there just to pass on knowledged, but to listen to what you have to say (Student 13); [...] the teacher sitting next to you favors learning [...]. You are closer, have more freedom to ask, willingness to listen and participate [...] (Student 16); [...] the teacher with a crooked posture in the chair [...] shows disinterest in what the student is saying (Student 2); [...] the teacher standing on the board, the very position of the body in front of the group facilitates learning (Student 10); [...] the teacher is standing, interested in seeing the student searching [...] (Student 12); there was a teacher in particular that used to move through the room space. He used to get up, walk, sit down ... this makes the discussions dynamic and we get more connected [...] (Student 9); He would saty on the wall, cross his arms, sit, walk. These movements then created dynamism in the group (Student 14).

\section{Second unit: the teacher's eyes}

The way the teacher looks, with attention, with respect, everything is transmitted in the form of looking (Student 4); it was a teacher who, when you were wrong, you would already get from the look (Student 5); the teacher would look at you, encouraging you [...] (Student 13); the confident look. Everything that is passed with confidence, you feel the learning (Student 15); the teacher looks around, he shows disinterest in what the student is saying (Student 2); [...] you are convinced that that is right, you have studied and with suspicious eyes, the teacher puts everything down (Student 5); [...] the teacher's gaze showed a seriousness that would scare us [...] (Student
7); [...] the teacher only takes a look and does not say whether it is right or wrong. What happens: it discourages us to get exposed e (Student 8).

\section{Third unit: the teacher's facial expressions}

Just in the expression: there were teachers who seemed calm, you were in a line of reasoning, doing very well [Student 6]; [...] facial expressions, evolving for you to conclude your reasoning, it facilitates (Student 7); we see on the face that the teacher is upset, then all the students tried to grow [...] (Student 11); [...] the very expression of dissatisfaction on the teacher's face when the group did not do well at that moment, encouraged students to go back to the questions and search [Student 12].

\section{Fourth unit: the teacher's appearance}

[...] teachers need to have a respectful way of dressing: no cleavage, no short skirt (Student 4); [...] the teachers put on a suit that does not attract attention, discreet [...] (Student 5); [...] teachers dress in light clothes, neutral tones to teach [...] (Student 11).

\section{Discussion}

The decoding units identified portray the assemblies that occur when nursing students learn the work of caring with the teacher's body. The word assembly refers to this mixture of bodies in a society, comprising all the attractions and repulsions, sympathies and antipathies, changes, alliances, penetrations and expansions that affect people of all kinds. ${ }^{\left({ }^{8}\right)}$ In this perspective, the availability to capture the subjective body elements involved in the higher education of nurses needs to be discussed. This is because the body contains a multiplicity of communications, capable of influencing the teaching-learning process, and therefore, must be taken into account in the performance of academic activities. ${ }^{(9)}$

The first decoding unit refers to the positioning and movements performed by the teacher's 
body in the teaching scenario. In the analysis, three pedagogical situations were found: sitting, standing and the movements performed by the teacher in the classroom.

With regard to the position of the teacher's body in the classroom, the distance between the bodies may mean social distance. It is proper for students to say that teachers must seek equality with them. There is an indication to the bodies that teach to be more attentive to the positioning adopted in the physical space, so that this may be no longer a negative factor in learning but, on the contrary, a factor that arouse attention and interest in learning. ${ }^{(9)}$ When the body of the teacher was seated in the teaching scene, that is, at the same level as the students, there were divergences in the statements, which led to the discussion of the effects of this position in facilitating and inhibiting the learning.

The main pleasant effects in the nursing students' opinion pointed to the freedom of expression, creation of bond, active listening; learning from the exchange of experiences and knowledge. The sitting position allowed the student to participate in the discussions about the curricular texts. Desire as the production of a professional identity, creation of the nurse, confrontation of powers, construction of new knowledge, power and life. ${ }^{(10)}$

When we analyze the contents of the statements, we notice that the positioning of the teacher's body in the chair was the object of observation of the students in the teaching-learning scenarios. The body of the teacher in the crooked sitting position was signified as disinterest in the discussions and had a negative impression on the apprehension of the curricular contents that were being collectivized. The teacher's position when teaching caring activities is a differential point of quality in the training of nurses to adopt ethical and political stances. If the professional adopts positions of little appreciation of pedagogical actions, there will be another kind of consequence for the educational practice. ${ }^{(9)}$

Regarding the standing position adopted by the teacher's body: curiously, this position, when taken in the classroom, produced pleasant effects in students to learn nursing. In this type of encounter, the bodies of the students were considered mere receptacles of knowledge, accustomed to receiving curricular contents related to diseases, health policies, care and management processes, among other notions applied to the different areas of the nursing profession. This vertical manner of training nurses takes place under a marked influence of a positivist model of science, centered on a pedagogical practice with a strong technical influence, where spatially specific health content focused on biological aspects emerges. ${ }^{(11)}$ In fact, this discourse invites us to think of the teacher's body as a vehicle transmitting power with movements that identifies him as a health professional daily affected by various control devices hatched in the network of life and that are analyzed by the nursing students in the classroom.

From the moment that the teaching-learning scenes were conducted by body movements, that is, the teacher dynamically walking, sitting, standing, crossing and uncrossing the arms, the nursing students had their attention awakened and learned the contents with greater ease. Yes, the teacher transmits information through gestures, postures, body orientations, organization of objects in the scenario, and even through the relationship of distance maintained with the students. All this gestures end up being used to facilitate the task of understanding messages that are quite significant in the learning process. ${ }^{(12)}$ The second decoding unit creates the opportunity to affirm that looking and seeing are different things. The students during class took time to see the teacher's body. In this observation, they identified the eyes as determining elements in the teachinglearning process in nursing. This is due to the fact that the teacher's gaze carries messages ranging from stimulus to disinterest for the contents discussed in the classroom. Consequently, the students were influenced by the movements of the teacher's eyes as well as the locations of the learning setting in which his visual field was designed to teach.

Be it the empty scenario or towards the bodies that learn, the way of looking was able to reveal 
approximations and distances with respect to the reception of a curricular message to be apprehended. ${ }^{(13)}$ Body that to create the role of being a nurse is not only communicated thorugh the eye-retina, eye-sclera, eye-pupil, but by invisible and sensitive orders, since they are perceived by the vibrating body. ${ }^{(14,15)}$ Thus, the main pleasant effects to students based on the way of looking of the teacher were loaded by messages of: welcome, attention, encouragement, confidence and clarity in the content taught. Contrarily, the sense that nursing students wanted to give in saying that some teachers do not look in the eyes when they teach was represented by: inhibition, fear, devaluation and reprobation of the contents considered in the classroom. Eyes, now understood as elements of power, where subjectivity is scrutinized and penetrated by discipline, and which are able to neutralize students in the teaching-learning scenes.

The third decoding unit refers to the facial expressions of the teacher. Body, understood as a sign, once the face starts to enact curricular texts that are projected with different meanings and effects on students. The statements showed that the teacher's facial expression changes constantly and can be decoded as positive from the moment that the students understand it as: quiet, to the point of stimulating the uninterrupted search for scientific knowledge in the field of nursing. On the other hand, they produced negative effects when they carried messages of discouragement, fear and retraction. In these encounters, nursing teachers-students, the signs need to be perceived, seen in different ways to account for the signifier and the expressed meaning. In this aspect, to look well means to concentrate on peculiar elements of the face, which presupposes a mental effort to decode their different forms and movements. (16) It is in this context that the teacher's facial expression is able to transmit many messages, which are perceived and interpreted by the students, and that guide their behavior in the classroom. ${ }^{(11)}$ Based on this, the importance of the teacher in knowing this form of non-verbal communication stands out as a way of identifying the interest of the class, and of analyzing their own behavior, which also influences the learning of the students. ${ }^{(17,18)}$

The fourth and final decoding unit represented by the clothes induced effects in the nursing students. The use of light, discrete and neutral tones transmitted messages of respect. The indicatives point that the teachers' clothes should be used with good sense, in a simple, informal, comfortable and discreet way. In addition, colors should be used as a resource, in accordance with the teacher's state of mind and with the social conventions of the institution in which the work is done. ${ }^{(19)}$ Before pausing the reflections, it is essential to exercise these dialogues focusing on the expressiveness of the body that teaches. Let us say that it is an opportunity to intensify the bets of contemporary thought, that is, to think about the limit between the domains of knowledge: art and health, objectivity and subjectivity. Thinking, then, on this border area based on a local context allowed to overcome the isolation of the knowledge and promptly raises the curiosity to know the reverberations of this investigation in other institutional contexts of superior education of nursing as a way of amplifying the problems and the questions that pervade the practice of teaching.

The findings of this study indicate that nursing students look at teachers during everyday encounters and identify elements in their bodies that influence the learning of curriculum texts delivered in the classroom. In this sense, the positioning, the body movements, the eyes, the face and the clothes of the teachers were determinants in the learning process of nursing students. The word "body" is believed to extrapolate beyond its organic limits, giving way to new readings in nursing higher education. The teacher's body attracts or rejects the student, that has desires, acts, feels and thinks from an intimate connection with life, and in this connectivity with the other generates effects and prints marks capable of giving shape to the nursing profession. Generalizing was not yet possible. Based on this, we considered the investigation of data from a single Higher Education Institution and the contemplation of the reality of students regularly 
enrolled in the last academic period as a limitation of the study. Therefore, these findings portray a specific reality that may differ from other contexts, curricula, and periods of training, in which the body of the teacher comes into contact with the training of nursing students.

With the certainty of the unfinished, the need to change the way of seeing and living the relationships between teachers and students is undeniable, based on the recognition of the body as an expressive element and unit of induction in the teaching-learning process. Thus, we recommended carrying out further studies on this phenomenon in other research scenarios, with the purpose of proving or refuting these findings. It is also important to point out the importance of opening spaces in universities for the discussion of the object "the teacher's body" with university students, teachers and managers, in order to enhance the teaching-learning processes in the Nursing field.

\section{References}

1. Silva PS, Silva CRL, Tonini T, Figueiredo NMA. Effects of teaching-learning strategies: an essay on the responses of body responses in the tutorial scenario. Rev. Pesqui. Cuidado Fundamental. 2016; 8(3):4725-32.

2. Figueiredo NMA, Tonini T, Santos I, Handem PC, Lopes LRF. Cuidado de enfermagem: espaço epistêmico de vivências de ensino a partir do ser cliente. Rev. Enferm. UERJ. 2012; 20(2):167-72.

3. Morel CMTM, Amado LAS. Práticas pedagógicas e produção de subjetividades: a atenção e as novas tecnologias. Psicol Estud. 2016; 21(4):687-97.

4. Minayo MCS. Análise qualitativa: teoria, passos e fidedignidade. Cien. Saude Colet. 2012; 17(3):621-6.

5. Ryngaert JP. Jogar, representar: práticas dramáticas e formação. São Paulo: Cosac Naify; 2009.

6. Silva CMSLMD, Silva PS. O curso de graduação em enfermagem e os significados oriundos da tutoria. Rev. Pesqui. Cuidado Fundamental. 2015; 7(1):1783-95.
7. Bardin L. Análise de conteúdo. Lisboa: Edições; 1977.

8. Deleuze G, Guattari F. Mil Platôs: Capitalismo e esquizofrenia. Rio de Janeiro: Editora 3; 1997.

9. Carreiro MA. A expressão corporal do professor como indutora da aprendizagem: o cuidado na semiotécnica. [Dissertation]. Rio de Janeiro: Universidade Federal Estado do Rio de Janeiro; 2004.

10. Paraíso MA. Currículo, Desejo e Experiência. Rev. Educ. Real. 2009; 34(2):277-94.

11. Berardinelli LMM, Santos MLSC. Repensando a interdisciplinaridade e o ensino de enfermagem. Texto Contexto - Enferm. 2005; 14(3):419-26.

12. Silva MJP. Comunicação tem remédio: a comunicação nas relações interpessoais em saúde. São Paulo: Gente; 1996.

13. Silva ME, Silva PS. Elementos da face do professor no cenário tutorial: implicações na formação de enfermeiros. Rev. Pesqui. Cuidado Fundamental. 2016; 8(1):3803-19.

14. Silva PS da, Diniz SOS, Tonini T, Figueiredo NMA. Creating the role of nurse: reflections for teaching through constantin stanislavski. Rev. Enferm. UFPE On Line. 2014; 8(supl. 2):3790-6.

15. Rolnik S. Cartografia sentimental: transformações contemporâneas do desejo. Rio Grande do Sul: Sulina; 2006.

16. Figueiredo NMA, Machado WCA. Tratado de Cuidados de Enfermagem: Médico Cirúrgico. São Paulo: Roca; 2012.

17. Paes da Silva MJ, Kalil de Freitas CR. Influencias do comportamento comunicativo verbal e não verbal do docente em sala de aula-visão dos alunos e docentes de enfermagem. Enferm. Glob [Internet]. 2003 [cited 2017 Jan 21]; 2(2):11. Available from:http://revistas.um.es/eglobal/ article/view/621/669

18. Azevedo AL, Araújo STC, Vidal VLL. Como o estudante de enfermagem percebe a comunicação com o paciente em saúde mental. Acta Paul. Enferm. 2015; 28(2):125-31.

19. Castro RKF, Silva MJP. Influências do comportamento comunicativo não-verbal do docente em sala de aula - visão dos docentes de enfermagem. Rev. Esc. Enferm. USP. 2001; 14(3):381-9. 